\title{
AT-Rich Interactive Domain-Containing Protein 2
}

National Cancer Institute

\section{Source}

National Cancer Institute. AT-Rich Interactive Domain-Containing Protein 2. NCI

Thesaurus. Code C101090.

AT -rich interactive domain-containing protein 2 (1835 aa, $197 \mathrm{kDa}$ ) is encoded by the human ARID2 gene. This protein is involved in the mediation of chromatin remodeling. 